\title{
Impact Of Islamic Work Ethics, Competencies, Compensation, Work Culture On Job Satisfaction And Employee Performance: The Case Of Four Star Hotels
}

\author{
Darwis Saban, Salim Basalamah, Achmad Gani, and Zainuddin Rahman
}

\begin{abstract}
The purpose of this study was to analyze the influence of the Islamic work ethic, competencies, compensation and work culture on the job satisfaction of fourstar hotel employees, analyze the influence of the Islamic work ethic, competencies, compensation and work culture on the four-star hotel employees performance, analyze the effect of job satisfaction on four-star hotel employee performance, and analyze the influence of the Islamic work ethic, competencies, compensation and work culture through job satisfaction on the four-star hotel employees performance. The study was conducted in 20 four star hotels in South Sulawesi with a population of 2,491 hotel employees. A sample of 345 respondents used the Slovin formula. Data from the questionnaire were analyzed using the Structural Equation Model using AMOS 18. The results of the study found that directly, there were nine hypotheses that gave a positive and significant influence, namely; Islamic work ethic, competencies, compensation and work culture for employees job satisfaction, furthermore Islamic work ethic, competencies, compensation and work culture for four-star hotel employee satisfaction and performance. Indirectly, there is one hypothesis that provides a positive and significant influence, namely the Islamic work ethic through job satisfaction on the four-star hotel employees performance. Indirectly, there are also three hypotheses that are found that provide positive and insignificant influences, namely competence, compensation and work culture through job satisfaction on the four-star hotel employees performance. Overall, either directly or indirectly provide a dominant influence is positive and significant, is a hypothesis first, fifth and tenth, the variable Islamic work ethic positive and significant impact on job satisfaction and employee performance, seen from the total effect and probability value that is greater than the other hypotheses.
\end{abstract}

Index Terms - Islamic work ethics, competence, compensation, work culture, job satisfaction, employee performance

\section{INTRODUCTION}

This research refers to the real conditions that are seen today, the increasing capacity and expansion of South Sulawesi, providing opportunities for more and more entrepreneurs to invest in the hotel sector that supports business and tourism activities that are developing in South Sulawesi as a gateway to Eastern Indonesia. The phenomenon seen shows that the development of the hotel service industry in South Sulawesi is supported by government policies that want to make Makassar and other cities a world city, where people come to visit and see the potential of the South Sulawesi Province in general and South Sulawesi in particular in various business activities, investment, and tourism that develop and have favorable prospects. Considering the importance of the hotel industry in South Sulawesi Province, the Government provides an opportunity for every public to participate in building construction activities, such as hotel business people who make hospitality industry opportunities for Eastern Indonesia specifically, so that they can be called city hotels, marked by the number of hotels with various classifications available in this city, ranging from five-star, four, three, two and one-star hotels, and jasmine is easily found in this city.

The rapid growth of business hotels has resulted in a high level of competition between hotels. For hotel entrepreneurs, this condition is not a big concern as long as the market share isstill available in providing opportunities for activities that make the hotel industry business a destination for business, events and tourism. Like one of them Makassar City is now recognized as one of the cities (Meeting, Incentive, Convention and Exhibition-MICE) in Indonesia and is the location of national and international scale meetings. The hotel management must try their best to utilize the market with maximum service to their guests. The above phenomenon for entrepreneurs engaged in hotel services seeks to build various partnerships with the government, entrepreneurs and stakeholders that have to date been growing and developing everywhere around the South Sulawesi region, various hotel classifications ranging from five-star hotels to with non star hotels.

Based on data from the South Sulawesi hospitality association shows that currently four-star hotels there are 18 hotel in Makassar City and two hotel in Tana Toraja, so there are a total of four-star hotels with 20 units, which have absorbed many employees engaged in hospitality services. Given the importance of this phenomenon, the hospitality services association in South Sulawesi seeks to capture and exploit this opportunity by improving the Islamic work ethic, competence, compensation, work culture, job satisfaction and employee performance so that it remains on the line of business development in the hospitality services industry.

Hospitality services in Indonesia are very potential to be developed and promoted considering that Indonesia is one of the destination countries for foreign and domestic tourists because it is supported by business, investment and tourism potential. Understanding the importance of human resource management is inseparable from the application of management functions in handling the activities of the hospitality service industry in the operational success of developing human resource management is inseparable from the ability to manage human potential and organizations engaged in hospitality services [1].

The important thing of developing the hospitality service industry in its management of the management functions mentioned above, namely the importance of improving the Islamic work ethic, employee competence, increasing compensation, improving work culture, increasing job 
satisfaction and employee performance in realizing the prospective more advanced hospitality services industry now and in the future. The success of hospitality management is always determined by the Islamic work ethic, competence, compensation, work culture which directly or indirectly influences job satisfaction and employee performance. Observing the phenomenon of fourstar hotel employee performance based on data obtained from the report on the achievement of employee performance, shows that within five years $(2013$ - 2017) that has not been realized in accordance with the expected target of above $90 \%$, as a standard reference assessing the employees performance of hotel according to management's assessment [2].

The phenomenon of evaluating the performance of fourstar hotel employees has not reached the realization target of above $90 \%$. Determination of the realization of above $90 \%$ is a standard assessment of achievement of targets that are categorized as successful by managers who assess employee performance. Employee performance appraisal in 2013 until 2017 for four-star hotels viewed from five assessments, namely in terms of quantity recently achieved ranged from $75.69 \%$ to $82.61 \%$ assessed based on the number of services provided, in terms of quality realization of the performance of four-star hotels achieved between $81.74 \%$ to $85.94 \%$ assessed based on satisfactory service quality, the efficiency of the realization of the performance of four star hotels ranged from $75.64 \%$ to $81.33 \%$ assessed based on the long process of service time provided, effectively the performance of new four star hotels was realized between $80.85 \%$ to $83.37 \%$ assessed based on the utilization of fund management, and loyalty to the performance of four-star hotels realized between $83.95 \%$ to $86.26 \%$ rated based on compliance with the leadership and organizational rules.

The phenomenon of four-star hotels above the percentage of performance has not reached the expected target of above $95 \%$. Generally four-star hotels that have the highest percentage of performance that is above $90 \%$ are only four hotels, Grand Clarion, Four Point, Gapura Beach and Toraja Heritage Hotel. Based on the data above, this shows that the performance of four-star hotels still needs to be improved and improved, especially related to the achievement of work that is not optimal in accordance with the expected targets. On this basis, the management needs to apply the theory of performance [3] that everyone who works gets results according to their performance. The manifestation of performance is assessed according to quantity, quality, efficiency, effectiveness and work loyalty. It can be seen that the performance of four-star hotel employees in quantity shows that the number of employees who have international professional certification is still lacking, such as experts in the field of hospitality, the quality of services provided by employees are still not in accordance with international standards, efficiently there are still often found inappropriate employees when working, effectively there are still employees who perform tasks not in accordance with procedures causing ineffective services provided, and still often found a low level of work loyalty marked by frequent work conflicts. This is a fact that is often found in four-star hotels in looking at the performance of hotel employees.

This is supported by a number of relevant previous studies, which examines performance with the object of research on hospitality services with the results of research showing that the most important thing that plays a role in improving hospitality performance is the human factor or the existence of human resources that provide services in the hospitality sector [4]. Furthermore, that the performance of hotel employees in general is influenced by the amount of salary and bonus incentives received. Employees' competence also influences their performance improvement, so that they do not produce work results in quantity, quality, efficiency and effectiveness as well as high loyalty. Understanding the achievement of employee performance realization that has not reached the target as expected, this is inseparable from the phenomenon of the low level of job satisfaction of employees in carrying out their work activities in the hotel industry. Means that satisfaction directly affects employee performance, can increase and decrease, depending on job satisfaction experienced or felt by employees [5].

Job satisfaction influences performance as long as job satisfaction is met. This means that every human or individual whose job satisfaction is fulfilled will try to improve his performance [6]. The phenomenon that becomes a fact about employee job satisfaction which tends to decrease and dissatisfied with the work itself is considered to be less attractive and monotonous because it is done routinely, employees rarely feel the challenges of work at work, opportunities for achievement are rarely developed, the value of compensation received is assessed not in accordance with the work performed, and leaders rarely provide promotions in accordance with the achievements. This fact causes low employee job satisfaction, thus affecting the low employee performance. On the basis of the phenomenon raised regarding decreased employee satisfaction, which affects employee performance, the hotel management should apply the two factors theory [7] that everyone is faced with two choices, happy or unhappy about the work interesting, choice of work challenges, opportunities for achievement, deserve compensation and deserve to be promoted. That is, satisfaction is the goal of most human resources in carrying out their work both personally and organization. This theory is important to be able to improve and increase job satisfaction with employee performance achievement.

The importance of performance and satisfaction in the concept of Islamic management has been mentioned (Qur'an Surah At Taubah verse 105); And say, "Do [as you will], for Allah will see your deeds, and [so, will] His Messenger and the believers. And you will be returned to the Knower of the unseen and the witnessed, and He will inform you of what you used to do.

This verse gives the view that everyone in work must be carried out in accordance with the achievement of performance and job satisfaction, because Allah and His Apostle ordered to work in accordance with your field of work. Including a hotel employee is required to be able to carry out work in accordance with the achievement of performance and job satisfaction. This is also supported by a number of relevant previous studies [8] which examines job satisfaction on performance with the results of the study there is a significant positive relationship between job 
satisfaction and performance. In this case management must pay more attention to increase satisfaction from employees who have an influence on improving performance. Furthermore, which shows the satisfaction and performance research is determined by the Islamic work ethic, competence, compensation and work culture that is applied $[9,10]$ One of the causes of hotel employee performance and satisfaction has increased or decreased due to work ethics held by employees. The work ethic of Islam in this understanding is the perspective of Muslims in responding, doing and acting in working according to the goals of the organization.

The one's indicator of work ethic is manifested as work behavior that is shown in the form of discipline, responsibility, hard work, rational and honest [11,12]. The implementation of the work ethic carried out by four and five star hotel employees in reality still needs to be improved, especially employee work discipline that often does not comply with applicable rules and working conditions, is capable of being responsible independently, is required to always work hard with high dedication, employees are expected to make rational decisions and should be brave enough to develop honesty at work.

The fact is still found hotel employees who have not been able to have high discipline in work, often neglecting mandated responsibilities, usually lazy to work, make irrational decisions and make irregularities in carrying out their work. As a result of the work ethic shown this causes employee performance and job satisfaction to decline. Work ethic that must be applied by employees in carrying out their work, can use the concept of Islamic work ethic in which the concept guides everyone to be able to have the confidence and enthusiasm to carry out their work with sincerity in achieving a goal as an embodiment that work is worship. The Islamic work ethic will guide employees to have a personality that is always disciplined in working, is responsible for carrying out the work mandate, always works hard full of sincerity, makes rational decisions according to beliefs and has an honest personality at work.

This view of the Islamic work ethic is relevant to the Holly Qur'an that; Say, "O my people, work according to your position; [for] indeed, I am working. And you are going to know who will have succession in the home. Indeed, the wrongdoers will not succeed (QS Al An'am: 135). The reality of the facts found in the field, the competence of employees engaged in hospitality services still need to be improved, especially relating to knowledge, skills , experience, attitude of mastery, expertise and skills, related to the field of service to hotel guests or customers. The real condition is that there are still many hotel employees who are difficult to carry out their duties because they do not have hotel knowledge, are still less skilled in providing hospitality services, work experience in the hospitality sector is still lacking, mastery attitude in the field of hospitality is still low, expertise in the hospitality sector is not reliable and skills in serving guests who are still lacking. People who work in the hotel sector should have competencies that support job satisfaction and employee performance. The window theory of competence (window theory), states that organizational success is determined by assessing the potential of people who compete.
Competency assessment is assessed based on potential Human resources in the form of knowledge, skills, experience, mastery attitude, expertise and skills. The higher the competency of the individual, the easier it is to provide job satisfaction and improve performance. This is supported by a number of relevant previous studies research showing that the results of competency research have a positive and significant effect on commitment, job satisfaction and employee performance [13]. There is a positive and significant correlation of competence, work environment and compensation to employee performance $[14,15]$.

Including the phenomenon of compensation received by employees in fact employees are still demanding to increase compensation in accordance with the work achieved. Visible compensation as an organizational policy has not been able to improve employee welfare, even employees feel that the compensation they receive has not been proportional to the demands of what the employee is doing. As a result of work compensation received by employees is low, this affects job satisfaction and decreases employee performance. This can be seen by employees being diligent and diligent at work if every work carried out is compensated as a remuneration and if not compensated the tendency of employees to be lazy to work and often postpone work given to him. This is a phenomenon that compensation has a role in an organization to increase employee satisfaction and performance. To improve work satisfaction and employee performance due to the low compensation received by employees, it is necessary to consider the application of the award theory $[16,17]$ that everyone in the organization works to get an award receiving compensation in accordance with the rewards for services rendered to organization. The award in the form of compensation is an important factor that concerns every person in the organization to meet satisfaction and improve performance.

This is supported previous studies that a positive correlation and significant compensation for employee performance $[18,19]$. Job satisfaction and performance of hotel employees are largely determined by the incentives that are acceptable to each hotel employee as motivation to work better. Other considerations that need to be addressed in relation to the development of the hospitality services industry are the importance of inculcating a work culture, especially those relating to organizational philosophy, emotional relations, organizational progress and service to the organization where employees work in order to develop and provide added value for hotel services [20].

We observed, the real conditions found in hotel employees, many do not have a work culture, especially the lack of understanding of the philosophy of the founders of the organization in advancing the hotel industry, the lack of attention of the hotel in understanding the planting of emotional relations between employees and the organization, the development of commitments about organizational progress that must be addressed, and the still low level of dedication to work to feel a sense of belonging. This has caused the low work culture of employees to improve job satisfaction and performance.

The organization strengthening theory [21,22], states that strong organization is determined by work culture. The assessment of work culture is inseparable from the 
inculcation of the founder's philosophy, emotional connection, organizational progress and service. This is supported previous studies [23], with the results of research on improving the performance of hotel employees through opportunities to improve competency of hotel employees, proper compensation and work culture that supports each employee to advance the hotel where they work.

The work culture research from each different hotel to the attention of each employee to understand the importance of the main work culture related to organizational philosophy, emotional relationships, organizational progress and service to the organization where employees work in order to develop and provide added value for hotel services. Through competence, compensation and work culture in the development of hotel employee resources, employees are expected to be able to show their job satisfaction [24].

The real conditions that show employees are often dissatisfied in carrying out their profession as seen employees can not show the achievement of satisfactory work goals, do not show satisfactory achievement, do not achieve satisfactory realization, the achievement of unsatisfactory targets and the disappointment experienced in carrying out his profession. This can be seen from the achievement of work goals, work performance, realization, targets, and welfare while working in the field of hospitality services, which is not satisfactory, so that employees express disappointment and inconvenience to work due to perceived job dissatisfaction. As with job satisfaction, employees are also required to be able to improve their performance. However, real conditions indicate that the resulting performance is not realized optimally, so that the work results shown by employees are not realized in quantity, work less quality, do inefficient and effective work in services and are less loyal in carrying out work activities. Given the importance of phenomena based on real conditions according to the facts found supported by several theories, so that it appears the understanding of gap research and theory.

\section{LITERATURE REVIEW}

In this study there were four observed variables consisting of two exogenous variables and two endogenous variables. Exogenous variables in this study consist of Islamic work ethic, competence, compensation and work culture. Whereas endogenous variables are intervening variables namely job satisfaction and the dependent variable namely employee performance.

\section{A. Islamic Work Ethic}

The development and empowerment of human resources is a process to improve human knowledge, expertise and Work ethic is a set of positive behaviors rooted in fundamental beliefs accompanied by total commitment to an integral work paradigm [25]. Work ethic is an attitude that arises from one's own will and awareness based on a system of cultural values orientation towards work. A professional work ethic is a set of positive work behavior that is rooted in a thick awareness, fundamental beliefs, and total commitment to an integral work paradigm [26].

$\mathrm{H}_{1} \quad$ Islamic work ethic has positive and significant effect on job satisfaction of four-star hotel employees in South Sulawesi.
$\mathrm{H}_{2}$ Islamic work ethic has a positive and significant effect on the performance of four-star hotel employees in South Sulawesi.

\section{B. Competence}

The elements that build competence in the form of work knowledge, skills, experience, attitudes in work mastery and expertise. The higher one's work knowledge, the more skilled in developing work creativity according to the level of experience, mastery attitude and expertise in the occupied field of work [27,28,29].

$\mathrm{H}_{3} \quad$ Competence has a positive and significant effect on job satisfaction of four-star hotel employees in South Sulawesi.

$\mathrm{H}_{4} \quad$ Competence has a positive and significant effect on the performance of four-star hotel employees in South Sulawesi.

\section{Compensation}

The concept of compensation applied in the hotel industry refers to an understanding of the classification of compensation, where the concept of compensation is known in two general forms namely financial compensation and non-financial compensation. Financial compensation consists of direct compensation and indirect compensation, while non-financial forms of compensation are in the form of the environment and available work facilities [30].

$\mathrm{H}_{5} \quad$ Compensation has a positive and significant effect on job satisfaction of four-star hotel employees in South Sulawesi.

$\mathrm{H}_{6} \quad$ Compensation has a positive and significant effect on the performance of four-star hotel employees in South Sulawesi.

\section{Work Culture}

Work culture or work culture is a set of important assumptions regarding work activities in which there are elements of sensitivity, freedom, courage and openness to produce good work [31].

$\mathrm{H}_{7} \quad$ Work culture has a positive and significant effect on job satisfaction of four-star hotel employees in South Sulawesi.

$\mathrm{H}_{8} \quad$ Work culture has a positive and significant effect on the performance of four-star hotel employees in South Sulawesi.

\section{E. Job Satisfaction}

Job satisfaction is a positive emotional state from evaluating one's work experience. Job dissatisfaction arises when these expectations are not met. Job satisfaction has many dimensions, in general it is satisfaction in the work itself, salary, recognition, the relationship between supervisors and workforce, and opportunities for advancement [32].

$\mathrm{H}_{9} \quad$ Job satisfaction has a positive and significant effect on the performance of four-star hotel employees in South Sulawesi.

\section{F. Employee performance}

The employee performance is the achievement of results that have added value. The added value in question is the work that is measured in quantity, quality, efficient and effective. Whereas related to behavior can be categorized according to the level of loyalty in contributing to the increase in value added [33]. 
$\mathrm{H}_{10}$

Islamic work ethic through job satisfaction has a positive and significant effect on the performance of four-star hotel employees in South Sulawesi.

$\mathrm{H}_{11} \quad$ Competence through job satisfaction has a positive and significant effect on the performance of fourstar hotel employees in South Sulawesi.

$\mathrm{H}_{12}$ Compensation through job satisfaction has a positive and significant effect on the performance of four-star hotel employees in South Sulawesi.

$\mathrm{H}_{13} \quad$ Work culture through job satisfaction has a positive and significant effect on the performance of fourstar hotel employees in South Sulawesi.

\section{RESEARCH METHOD}

This research is a explanatory research, we will be designed to answer the problems that have been formulated and the objectives to be achieved and test the hypothesis. Research locations in several four-star hotels in South Sulawesi as research objects to see the effect of competence, compensation and organizational culture on job satisfaction and employee performance. Research time is scheduled for four months from April to July 2018. There are two types of research, namely quantitative and qualitative research. Sources of data in this study consisted of primary and secondary data. Data collection techniques (instruments) used were observation, questionnaire, interview and documentation. The population in this study were all fourstar hotel employees in South Sulawesi from 20 hotels registered at the Indonesian Hotel and Restaurant Association (PHRI) of 2,491 employees both Islamic and non-Islamic as of June 2018. Withdrawal of the sample was carried out using the Slovin formula to minimize total population by setting a degree of confidence of $5 \%$ representing the sample used as respondents. So the total sample of the study was 345 respondents. Data analysis techniques used in explaining the phenomena in this study are descriptive statistical analysis techniques and Structural Equation Modeling (SEM) analysis.

\section{RESEARCH RESULTS}

The eligibility testing of the SEM model is intended to determine whether the proposed SEM model is appropriate (eligible). There are several test indices in SEM analysis, namely the probability of Chi Square (CMIN), CMIN / DF, RMR, GFI, AGFI, TLI, CFI, and RMSEA tests. The criterion using chi square (CMIN) states that when the probability value of chi-square is $\geq$ level of significant (alpha) then the formed SEM model is eligible. worth it. The criteria for using GFI and AGFI state that when the Goodness of fit $\geq 0.90$ then the SEM model is formed to be eligible. The criteria for using TLI and CFI state that when the Goodness of fit $\geq 0.95$ then the SEM model is formed to be eligible. And the criterion for using RMR states that when the Goodness of fit $\leq 0.05$ then the SEM model that is formed is considered eligible. The criterion for using RMSEA states that when the value of RMSEA $\leq 0.08$ then the SEM model formed is considered to be eligible [34]. The results of the SEM model eligibility test are summarized in the following the Table:

\begin{tabular}{lcc}
\multicolumn{4}{c}{ TABLE I: GOODNESS OF FIT MODEL TEST } \\
\multicolumn{1}{c}{ Index } & Goodness of Fit & Criterion \\
\hline Chi Square & $251.758(\mathrm{p}$ value $=0.957)$ & $\mathrm{p}$ value $>$ alpha $5 \%$ \\
CMIN/DF & 0.862 & $\leq 2.00$ \\
CFI & 1.000 & $\geq 0.95$ \\
TLI & 1.006 & $\geq 0.95$ \\
RMSEA & 0.000 & $\leq 0.08$ \\
RMR & 0.000 & $\leq 0.05$ \\
GFI & 0.957 & $\geq 0.9$ \\
AGFI & 0.926 & $\geq 0.9$ \\
\hline
\end{tabular}

Based on the summary of goodness of fit (see the Table I.) it can be seen that the chi-square index, CMIN / DF, CFI, TLI, RMSEA, RMR, GFI, and AGFI have criteria that match the cut-off value, so that all six indexes have been met. Thus the construct that has been formed is declared appropriate (feasible). Hypothesis testing is intended to test whether there is a direct influence of exogenous variables on endogenous variables. Hypothesis testing can be known through the t-statistics. The test criteria state that if the path coefficient is positive and the $p$-value $\leq$ level of significance (alpha $(\alpha)=5 \%$ ) then it is stated that there is a positive and significant influence of exogenous variables on endogenous variables. The results of the analysis can be known through the summary in the following the Table:

\begin{tabular}{llcc} 
TABLE II: THE DIRECT EFFECT HYPOTHESIS & & \\
\hline \multicolumn{1}{c}{ Exogenous } & \multicolumn{1}{c}{ Endogenous } & CR & P-value \\
\hline Islamic Work Ethics & Job satisfaction & 14.894 & 0.000 \\
Islamic Work Ethics & Employee performance & 3.140 & 0.002 \\
Competence & Job satisfaction & 2.261 & 0.024 \\
Competence & Employee performance & 3.077 & 0.002 \\
Compensation & Job satisfaction & 6.361 & 0.000 \\
Compensation & Employee performance & 2.144 & 0.032 \\
Work culture & Job satisfaction & 6.144 & 0.000 \\
Work culture & Employee performance & 2.319 & 0.020 \\
Job satisfaction & Employee performance & 2.025 & 0.043 \\
\hline
\end{tabular}

The hypothesis testing of the influence of the Islamic work ethic on job satisfaction produces a path coefficient of 0.905 and a p-value of 0.000 . This shows that the path coefficient is positive and p-value <level of significance (alpha $(\alpha)=5 \%$ ). Therefore, it can be interpreted that there is a positive and significant influence of Islamic work ethic on job satisfaction. The influence of the Islamic work ethic on performance produces a path coefficient of 0.590 and a p-value of 0.002 . This shows that the path coefficient is positive and p-value $<$ level of significance (alpha $(\alpha)=5 \%$. Therefore, it can be interpreted that there is a positive and significant influence of the Islamic work ethic on performance. The effect of competence on job satisfaction produce a path coefficient of 0.073 and a p-value of 0.024 . This shows that the path coefficient is positive and $\mathrm{p}$-value $<$ level of significance (alpha $(\alpha)=5 \%$ ). Therefore, it can be interpreted that there is a positive and significant effect competence on job satisfaction.

The effect of competence on performance produces a path coefficient of 0.093 and p-value of 0.002 . Therefore, it can 
be interpreted that there is a positive and significant effect of competence on performance, The effect of compensation on satisfaction work produces a path coefficient of 0.231 and a p-value of 0.000 . This shows that the path coefficient is positive and p-value $<$ level of significance (alpha $(\alpha)=$ $5 \%$ ). Therefore, it can be interpreted that there is a positive and significant effect of compensation on job satisfaction. The effect of compensation on performance produces a path coefficient of 0.117 and a $p$-value of 0.032 . Therefore, it can be interpreted that there is a positive and significant effect of compensation on performance.

The influence of work culture on job satisfaction produces a path coefficient of 0.212 and a p-value of 0.000 . Therefore, it can be interpreted that there is a positive and significant influence of work culture on job satisfaction. The influence of work culture on performance produces a path coefficient of 0.117 and a p-value of 0.020 . This shows that the path coefficient is positive and p-value <level of significance (alpha $(\alpha)=5 \%$ ). Therefore, it can be interpreted that there is a positive and significant influence of work culture on performance. The effect of job satisfaction on performance produces a path coefficient of 0.399 and a p-value of 0.043. Therefore, it can be interpreted that there is a positive and significant influence of job satisfaction on performance.

The indirect effect testing is intended to test whether there is an indirect influence of exogenous variables on endogenous variables through mediating variables. to see the indirect effect is done through the calculation of the Sobel test (computing sobel test of mediation for Baron \& Kenny Approach) with the following calculation results:

TABLE III: GOODNESS OF FIT

\begin{tabular}{|c|c|c|c|c|}
\hline Exogenous & Mediation & Endogenous & $\begin{array}{c}\text { Indirect } \\
\text { Effect } \\
\text { (Sobel } \\
\text { Test) } \\
\end{array}$ & SE \\
\hline $\begin{array}{l}\text { Islamic Work } \\
\text { Ethics }\end{array}$ & $\begin{array}{l}\text { Job } \\
\text { satisfaction }\end{array}$ & $\begin{array}{l}\text { Employee } \\
\text { performance }\end{array}$ & 0.361 & 2.014 \\
\hline Competence & $\begin{array}{l}\text { Job } \\
\text { satisfaction }\end{array}$ & $\begin{array}{l}\text { Employee } \\
\text { performance }\end{array}$ & 0.029 & 1.505 \\
\hline Compensation & $\begin{array}{l}\text { Job } \\
\text { satisfaction }\end{array}$ & $\begin{array}{l}\text { Employee } \\
\text { performance }\end{array}$ & 0.092 & 1.934 \\
\hline Work culture & $\begin{array}{l}\text { Job } \\
\text { satisfaction }\end{array}$ & $\begin{array}{l}\text { Employee } \\
\text { performance }\end{array}$ & 0.085 & 1.927 \\
\hline
\end{tabular}

The Islamic work ethic on employee performance through job satisfaction produces Sobel test results for indirect effect of 0.361 and $p$-value of 0.044 . This shows that the indirect effect is positive with a p-value $<0.05$. Therefore, it can be interpreted that there is a positive and significant influence of the Islamic work ethic on performance through job satisfaction. The influence of competence on performance through job satisfaction produces Sobel test results for indirect effects of 0.029 and p-value of 0.132 . This shows that the indirect effect is positive with p-value $>0.05$. Therefore, it can be interpreted that there is a positive and insignificant influence of competence on performance through job satisfaction.

The effect of compensation on employee performance through job satisfaction produces Sobel test results for indirect effects of 0.092 and p-values of 0.053 . This shows that the indirect effect is positive with $p$-value $>0.05$. Therefore, it can be interpreted that there is a positive and insignificant effect of compensation on performance through job satisfaction. The influence of work culture on employee performance through job satisfaction produces Sobel test results for indirect effect of 0.085 and p-value of 0.054 . This shows that the indirect effect is positive with p-value $>0.05$. Therefore, it can be interpreted that there is a positive and insignificant influence of work culture on performance through job satisfaction.

Conversion of path charts into structural models is intended to determine the direct and indirect effects based on SEM analysis results as the following the Table:

\begin{tabular}{|c|c|c|c|c|c|}
\hline Exogenous & $\begin{array}{l}\text { Variable } \\
\text { Mediation } \\
\end{array}$ & Endogenous & P-value & $\begin{array}{l}\text { Direct } \\
\text { effect }\end{array}$ & $\begin{array}{c}\text { Indirect } \\
\text { effect }\end{array}$ \\
\hline $\begin{array}{l}\text { Islamic Work } \\
\text { Ethics }\end{array}$ & - & $\begin{array}{l}\text { Job } \\
\text { satisfaction }\end{array}$ & 0.000 & 0.905 & - \\
\hline $\begin{array}{l}\text { Islamic Work } \\
\text { Ethics }\end{array}$ & - & $\begin{array}{l}\text { Employee } \\
\text { performance }\end{array}$ & 0.002 & 0.590 & - \\
\hline Competence & - & $\begin{array}{l}\text { Job } \\
\text { satisfaction }\end{array}$ & 0.024 & 0.073 & - \\
\hline Competence & - & $\begin{array}{l}\text { Employee } \\
\text { performance }\end{array}$ & 0.002 & 0.093 & - \\
\hline Compensation & - & $\begin{array}{l}\text { Job } \\
\text { satisfaction }\end{array}$ & 0.000 & 0.231 & - \\
\hline Compensation & - & $\begin{array}{l}\text { Employee } \\
\text { performance }\end{array}$ & 0.032 & 0.117 & - \\
\hline Work culture & - & $\begin{array}{l}\text { Job } \\
\text { satisfaction }\end{array}$ & 0.000 & 0.212 & - \\
\hline Work culture & - & $\begin{array}{l}\text { Employee } \\
\text { performance }\end{array}$ & 0.020 & 0.117 & - \\
\hline $\begin{array}{l}\text { Job } \\
\text { satisfaction }\end{array}$ & - & $\begin{array}{l}\text { Employee } \\
\text { performance }\end{array}$ & 0.043 & 0.399 & - \\
\hline $\begin{array}{l}\text { Islamic Work } \\
\text { Ethics }\end{array}$ & $\begin{array}{l}\text { Job } \\
\text { satisfaction }\end{array}$ & $\begin{array}{l}\text { Employee } \\
\text { performance }\end{array}$ & 0.044 & 0.590 & 0.361 \\
\hline Competence & $\begin{array}{l}\text { Job } \\
\text { satisfaction }\end{array}$ & $\begin{array}{l}\text { Employee } \\
\text { performance }\end{array}$ & 0.132 & 0.093 & 0.029 \\
\hline Compensation & $\begin{array}{l}\text { Job } \\
\text { satisfaction }\end{array}$ & $\begin{array}{l}\text { Employee } \\
\text { performance }\end{array}$ & 0.053 & 0.117 & 0.092 \\
\hline Work culture & $\begin{array}{l}\text { Job } \\
\text { satisfaction }\end{array}$ & $\begin{array}{l}\text { Employee } \\
\text { performance }\end{array}$ & 0.054 & 0.212 & 0.085 \\
\hline
\end{tabular}

Based on the table above, interpreted as follows, the direct effect of the Islamic work ethic on job satisfaction by $0.905 *$ states that the Islamic work ethic has a positive and significant effect on job satisfaction. This means that the higher the Islamic work ethic, it tends to increase job satisfaction. The direct effect of the Islamic work ethic on performance by $0.590 *$ states that the Islamic work ethic has a positive and significant effect on performance. This means that the higher the Islamic work ethic, it tends to improve performance. Direct effect of competence on job satisfaction of $0.073 *$ states that competence has a positive and significant effect on job satisfaction. This means that the higher the competence, it tends to increase job satisfaction.

The Direct effect of competence on performance of 0.093 * states that competence has a positive and significant effect on performance. This means that the higher the competency, it tends to improve performance. The Direct effect compensation for job satisfaction of $0.231 *$ states that compensation has a positive and significant effect on job 
satisfaction. This means that the higher the compensation, it tends to increase job satisfaction. The Direct effect compensation for performance of $0.117 *$ states that compensation has a positive and significant effect on performance. This means that the higher the compensation, it tends to improve performance.

The direct effect of work culture on job satisfaction by $0.212 *$ states that work culture has a positive and significant effect on job satisfaction. This means that the better the work culture, the more likely it is to increase job satisfaction. The direct effect of work culture on performance by $0.117 *$ states that work culture has a positive and significant effect on performance. This means that the better the work culture, the more likely it is to improve performance. The direct effect of job satisfaction on performance of $0.399 *$ states that job satisfaction has a positive and significant effect on performance. This means that the higher job satisfaction, it tends to improve performance. The direct effect of the Islamic work ethic on performance through job satisfaction of $0.361 *$ states that the Islamic work ethic has a positive and significant effect on performance through job satisfaction. This means that the higher job satisfaction caused by the higher Islamic work ethic, it tends to improve performance.

The indirect effect of competency on performance through job satisfaction by $0.029 *$ states that competence has a positive and not significant effect on performance through job satisfaction. This means that higher job satisfaction caused by higher competencies tends to increase performance, even though the increase is not significant. The indirect effect of compensation on performance through job satisfaction by $0.092 *$ states that compensation has a positive and not significant effect on performance through job satisfaction. This means that the higher job satisfaction caused by the higher compensation will tend to improve performance, even though the increase is not significant. The indirect effect of work culture on performance through job satisfaction of $0.085 *$ states that work culture has a positive and not significant effect on performance through job satisfaction. This means that the higher job satisfaction caused by the better work culture, it tends to improve performance, although the increase is not significant.

\section{CONCLUSION}

The Islamic work ethic has a positive and significant effect on job satisfaction. Employees in carrying out work in the field of hospitality have applied a work ethic in the form of discipline, responsibility, hard work, rational consideration and honesty to realize the job satisfaction of four-star hotel employees in South Sulawesi; The Islamic work ethic has a positive and significant effect on employee performance. The application of the work ethic has been actualized in improving performance in accordance with the achievement of the work of four-star hotel employees in South Sulawesi; The competence has a positive and significant effect on job satisfaction. Employees show their potential in hotel services according to their knowledge, skills, experience, mastery attitude, expertise and skills to realize the job satisfaction of four-star hotel employees in South Sulawesi.
The competence has a positive and significant effect on employee performance. The application of competencies possessed by employees in the hotel sector supports the profession to improve the performance of four-star hotel employees in South Sulawesi; The compensation has a positive and significant effect on job satisfaction. Each employee receives a service reward in the form of salary, incentives, benefits and work facilities, to realize the job satisfaction of four-star hotel employees in South Sulawesi; The compensation has a positive and significant effect on employee performance. Application of compensation as compensation for work occupied by employees and a consideration for employees to pursue their work in improving the performance of four-star hotel employees in South Sulawesi.

The work culture has a positive and significant effect on job satisfaction. Employees apply the philosophy of working habits in hotels according to work innovation, attention, results oriented, solid, aggressive work team and maintain work stability as a form of job satisfaction of four star hotel employees in South Sulawesi; The work culture has a positive and significant effect on employee performance. The application of work culture has become a basic philosophical habit that must be instilled by employees in carrying out work to improve the performance of four-star hotel employees in South Sulawesi; The job satisfaction has a positive and significant effect on employee performance. Employees have developed job satisfaction as an expression of feelings of pleasure and pride in pursuing the hospitality sector to improve the performance of four-star hotel employees in South Sulawesi.

The Islamic work ethic through job satisfaction has a positive and significant effect on employee performance. The implementation of the Islamic work ethic plays an important role in realizing employee job satisfaction to do interesting work, happy to accept work challenges, achievement, getting awards and promotions in running jobs to improve the performance of four-star hotel employees in South Sulawesi; The competence through job satisfaction has a positive and not significant effect on employee performance. The application of competence has been applied by employees in realizing work satisfaction as seen by differences in each employee's competency, which indirectly has an insignificant effect on the performance of four-star hotel employees in South Sulawesi; The compensation through job satisfaction has a positive and not significant effect on employee performance. The application of compensation has been applied to employees in accordance with remuneration received to realize job satisfaction, but there are differences in each employee's compensation based on experience and position, which indirectly has an insignificant effect on the performance of four-star hotel employees in South Sulawesi; and the work culture through job satisfaction has a positive and not significant effect on employee performance. The implementation of work culture has been applied by employees to realize job satisfaction, but there are differences seen from employees in actualizing work culture because there are different habits of each employee at work, which indirectly has an insignificant effect on the performance of four-star hotel employees in South Sulawesi. 


\section{REFERENCES}

[1] Marzuki, A. (2008). Impacts of tourism development in Langkawi Island, Malaysia: a qualitative approach. International Journal of Hospitality and Tourism Systems, 1(1), 1.

[2] Hasan, S. (2008). Experiences of Third Sector Governance in Asia: A Political Economy Analysis. In Comparative third sector governance in Asia. Springer, New York, NY.

[3] Schermerhorn, J. R., Hunt, J., Osborn, R., \& Passmore, J. (2006). Organizational Behaviour. Langara College.

[4] Kazak, A. N., Lukyanova, Y. Y., \& Shamayeva, N. (2019, August). Internet demand marketing analysis for Black sea resorts' touristy services. In IOP Conference Series: Earth and Environmental Science (Vol. 315, No. 3, p. 032001). IOP Publishing.

[5] Obeidat, B. Y., \& Abdallah, A. B. (2014). The relationships among human resource management practices, organizational commitment, and knowledge management processes: A structural equation modeling approach. International Journal of Business and Management, 9(3), 9.

[6] Mandon, James. (2008). The Human Resource People Satisfaction and Performance. Harvard Business School Press, Boston.

[7] Rivai, V. (2008). Manajemen Sumber Daya Manusia untuk Perusahaan, Bandung: PT. Remaja Rosda Karya.

[8] Almutairi, D. O. (2013). The relationship between leadership styles and organizational commitment: A test on Saudi Arabian Airline. World Review of Business Research, 3(1), 41-51.

[9] Latif, M. S., Ahmad, M., Qasim, M., Mushtaq, M., Ferdoos, A., \& Naeem, H. (2013). Impact of employee's job satisfaction on organizational performance. European Journal of Business and Management, 5(5), 166-171.

[10] Toban, C., \& Sjahruddin, H. (2016). The antecedent and consequence of Organizational Commitment and Job Satisfaction. Journal of Business and Management Sciences, 4(2), 26-33.

[11] Winardi, Hardjosoedarmo, (2005). The HR Paradigm in Work Performance. Rineka Cipta Publisher, Jakarta

[12] Alvin, Bonde. (2007). Competence in Technology and Potency of Human Resources. Published by Addison-Wesley Publishing Company.

[13] Syahrum, A., Brahmasari, I., \& Aju dan Nugroho, R. (2016). Effect of Competence, Organizational Culture and Climate of Organization to the Organizational Commitment, Job Satisfaction and the Performance of Employees in the Scope of Makassar City Government. International Journal of Business and Management Invention ISSN (Online), 2319-8028.

[14] Singarimbun, M., \& Effendi, S. (1995). Research Survey Methods, PT. Pustaka LP3ES, Jakarta.

[15] Beer \& Spector. (2004). Human Resource Management. Published by McGraw Hill, Ohio.

[16] Jackson, S. E., Schuler, R. S., Lepak, D., \& Tarique, I. (2012). 19 HRM practice and scholarship: a North American perspective. Handbook of research on comparative human resource management, 451.

[17] Hasanuddin, R., \& Sjahruddin, H. (2017). The structure of emotional intelligence, spiritual intelligence and its relationship with work enthusiasm and auditor performance. Structure, 3(1).

[18] Chen, I. H., Brown, R., Bowers, B. J., \& Chang, W. Y. (2015) Work-to-family conflict as a mediator of the relationship between job satisfaction and turnover intention. Journal of advanced nursing, 71(10), 2350-2363.

[19] Cleveland, Musk. (2008). Performance. Published by Harper T \& Row, New York

[20] Dekker, Mascule. (2007). Satisfaction and Application in Globalization Era. http://www.journalmotivation.com.id.

[21] Furtwengler, Dale. (2011). Performance. Published by Harper T \& Row, New York.

[22] Gibson, James L, Ivancevich, John M \& Donnely, James. (2004). Organizational Behavior, Structure, Process. $3^{\text {rd }}$, edt., Dallas, Business Publications, Inc.

[23] Ohara, Banham, J. (2005). Development of Performance by Human Resource Management. Published by Prentice Hall, New York.

[24] Terry, GR. (2008). Human Resource Management. Published by McGraw Hill, USA

[25] Ahmad, M. S. (2011). Work ethics: an Islamic prospective. Journal of Human Sciences, 8(1), 850-859.

[26] Khalid, M., Bashir, S., Khan, A. K., \& Abbas, N. (2018). When and how abusive supervision leads to knowledge hiding behaviors: An Islamic work ethics perspective. Leadership \& Organization Development Journal, 39(6), 794-806.
[27] Dhalman, Fred. (2008). Competence in Technology and Potency of Human Resource. Published by Addison-Wesley Publishing Company.

[28] Rafael (2008). The Competence toward Work Satisfaction on Airplane Company

[29] Donald, McEachern, Thomas. (2007). Competence of Personal in Prospective Theories. http://www.journalhumanresourcemanagement.com.id.।

[30] Stolovitch, Storryl, \& Keeps, Storey. (2007). Managing Resource and Performance. Buckingham: Open University $\mathrm{Pr}$

[31] Tunggal, Amin Widjaja. (2007). Theory and Cases of Organizational Culture. Harvarindo Publisher, Jakarta.

[32] Handoko, Hani T. (2004). Human Resource Management. BPFE Publisher, Yogyakarta

[33] Hersey, Paul \& Blanchard, Kenneth H. (2012). Management Organizational Behavior, Utilizing Human Resources. $4^{\text {th }}$. Ed. Englewood Cliffs, New Jersey, Prentice-Hall, Inc.

[34] Ferdinand, Augusty. (2011). Structural Equation Modeling in Management Research. Economic Faculty Diponegoro University, Semarang. 